申芳霞", 朱天乐, 牛牧童

北京航空航天大学空间与环境学院, 北京 102206

* 联系人, E-mail: fxshen@buaa.edu.cn

2017-10-11 收稿, 2017-11-15 修回, 2017-11-15 接受, 2017-12-07 网络版发表

国家重点研发计划(2017YFC0702800)、环境模拟与污染控制国家重点联合实验室专项经费(17K07ESPCP)和北京航空航天大学卓越百人专 项经费(ZG216S17A6)资助

\begin{abstract}
摘要大气污染物暴露与呼吸系统疾病、心脑血管疾病、神经退化性疾病之间的关系, 已被大量流行病学和基 于动物、细胞的毒理学所确认。促炎症效应是污染物尤其是颗粒物影响健康的重要机制之一。然而, 颗粒物通过何 种过程引起炎症效应，哪些组分是促炎症效应的关键因子，依然不清楚．多环芳烃、重金属等化学组分对颗粒物促 炎症效应的贡献已有大量报道. 细菌、真菌、病毒、花粉等微生物及其碎片构成的生物气溶胶，基于其配体特征，在 激活免疫系统引起炎症反应方面有独有的“优势”。但由于对生物气溶胶进行在线监测分析有较大困难，导致缺乏 对其种类、浓度等特征的全面了解，从而限制了对颗粒物中生物组分促炎症效应的认识。本文简单总结了大气颗 粒物的促炎症效应，从炎症效应机制、不同组分的炎症效应及生物化学组分协同作用 3 个方面进行了归纳，并提出 了开展大气污染健康效应研究的几点新的研究思路和方向建议.
\end{abstract}

关键词颗粒物, 生物气溶胶, 化学组分, 炎症效应, 协同炎症效应, 氧化损伤

20世纪30年代开始, 比利时马斯河谷烟雾、伦敦 烟雾、洛杉矶光化学烟雾等公害事件不断爆发, 造成 成千上万人死亡, 直接促进了世界各地清洁空气法 案的通过和实施. 但是在此阶段人们对气污染健康 效应的关注点主要集中于突发性的大规模污染事件. 20世纪90年代起美国的两项队列研究开启了气污染 与人体健康研究的新阶段, 人们逐渐意识到较低水 平的污染 (相对于伦敦烟雾事件等)对健康也有不可 忽视的影响. 心脑血管疾病(血管硬化、中风等)、呼 吸系统疾病、肺癌、肝损伤等非呼吸系统疾病、寿命 缩短的现状与气污染之间的因果关系越来越明 确 ${ }^{[1 \sim 7]}$. 以心血管疾病为例, 短到几小时至几周的
$\mathrm{PM}_{2.5}$ (粒径小于 $2.5 \mu \mathrm{m}$ 的大气细颗粒物)暴露, 可导致 死亡率上升，长期暴露可导致寿命缩减多达几年，而 降低 $\mathrm{PM}_{2.5}$ 浓度可有效降低上述风险 ${ }^{[8]} . \mathrm{PM}_{2.5}$ 质量浓 度每升高 $10 \mu \mathrm{g} / \mathrm{m}^{3}$, 造成人体收缩压升高 $1.4 \mathrm{mmHg}(1$ $\left.\mathrm{mmHg}=1.013 \times 10^{5} \mathrm{~Pa}\right)$, 脉搏压升高 $1.0 \mathrm{mmHg}$, 动脉 压升高 $0.8 \mathrm{mmHg}$, 同时 $10 \mathrm{ppb}\left(20.53 \mu \mathrm{g} / \mathrm{m}^{3}\right)$ 的二氧化 氮 $\left(\mathrm{NO}_{2}\right)$ 上升伴随着 $0.4 \mathrm{mmHg}$ 的脉冲压上升,一定程 度上解释了当前心脑血管疾病发病率和致死率不断 上升的问题 ${ }^{[9]}$. 儿童作为易感人群, $\mathrm{PM}_{2.5}$, 二氧化硫 $\left(\mathrm{SO}_{2}\right), \mathrm{NO}_{2}$ 等污染物暴露造成的哮喘、心脑血管疾病 患病风险上升 ${ }^{[10 ~ 12]}$. 此外, 关于气污染与阿尔茨海 默症等神经退化性疾病关系的研究也越来越多, 2015 
年的一项研究表明长期暴露于 $\mathrm{PM}_{2.5}$ 可导致神经退化 性疾病的第一次门诊时间提前 ${ }^{[13 \sim 16]}$. 每年因 $\mathrm{PM}_{2.5}$ 暴 露过早死亡的人数超过 300 万人 ${ }^{[17]}$.

基于呼吸道上皮细胞、肺部巨噬细胞、胶质细胞、 动物等毒理学实验和流行病学研究开展了大量大气 污染的健康影响机制研究, 结果表明局部炎症、系统 性炎症、神经性炎症等是重要的病理学机制, 其中污 染物的氧化能力及其在人体肺部造成的氧化压力对 机体内氧化还原平衡和局部及系统性炎症免疫反应 有重要影响 ${ }^{[4,18 ~ 23]}$. 尽管如此, 当前对于大气污染导 致不利健康效应的关键因子仍不清楚. 由于颗粒物 组分复杂, 仅根据颗粒物粒径难以解释其健康效应, 来源及组分在颗粒物生物学效应中的重要性日益凸

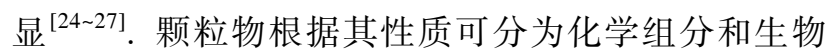
组分. 生物组分包括两部分, 一部分是生物源释放的 挥发性有机污染物(volatile organic compound, VOC) 等气态污染物在空气中经过二次转化生成的二次有 机气溶胶, 如植物源异戊二烯; 另一部分包括细菌、 真菌、病毒、花粉等微生物及其碎片、动植物源性蛋 白等. 化学组分主要包括硫酸盐、硝酸盐、铵盐、无 机碳、有机碳、金属、地壳元素、低挥发性有机物等. 哪些组分是导致颗粒物炎症效应的关键因素, 当前 还没有一致答案.

免疫系统是机体识别和清除非已进而维持健康 的保护网, 分为天然免疫系统和适应性免疫系统, 是 人类在长期进化过程中形成的, 其免疫能力是通过 感知元件 “受体”识别抗原和各类环境因素等 “配体” 后实现的. 当受体分子和配体分子结合后, 才可实现 信号转导, 从而将细胞外信号转化为胞内生化响应 事件. TOLL样受体(toll-like receptor, TLR)是最早发 现的模式识别受体, 其发现人比尤勒、霍夫曼教授在 2011 年被授予诺贝尔生理学或医学奖 ${ }^{[28]}$. 炎症反应 是免疫系统的受体识别配体后, 由不同类型的细胞 分泌促炎症介质(类花生酸、细胞因子、趋化因子等) 诱导启动的免疫防御行为. 来自于微生物的保守组 分、损伤相关分子模式等, 是重要的配体分子 ${ }^{[28]}$. 免 疫系统的这种工作模式和生物组分的配体特征使得 研究颗粒物中的生物组分进而解释颗粒物的健康效 应显得尤为必要和迫切. 经过几十年的流行病学观 察研究、人群实验、实验室研究等, 科学界仍未搞清 楚大气污染威胁人类健康的关键因素, 这或许是由 于对颗粒物中的生物组分认识不足, 导致不能完全
解释其中的关键原因.

\section{1 大气颗粒物生物化学组分的促炎症效应}

人体免疫系统在受到外界刺激和组织损伤时会 启动炎症反应, 其中参与诱导的炎症介质包括细胞 因子(白细胞介素-6(interleukin 6, IL-6), IL-8, IL-1; 肿瘤坏死因子(tumor necrosis factor, TNF)等)、前列腺 素(Prostaglandin, PG)和白细胞三烯(Leukotriene)等脂 类介质、C-反应蛋白 $(\mathrm{C}$-reactive protein, CRP)等. 急 性炎症反应典型症状包括红、肿、热、痛四种，主要 表现为白细胞上升, 慢性炎症反应主要是由于上述 炎症介质等持久性存在而导致的.

\section{1 颗粒物化学组分的促炎症效应}

越来越多的研究表明不同类型的疾病均与炎症 尤其是慢性炎症反应相关. 动物实验、细胞实验、流 行病学研究等提供了丰富的关于大气污染物尤其是 颗粒物在促进炎症介质信号分子上升方面的影响, 如表1所示. 糖尿病发病率近年来不断上升, 小鼠研 究表明 $\mathrm{PM}_{2.5}$ 可通过影响内脏脂肪组织炎症、肝脂质 代谢等途径调控小鼠的胰岛素抗性 ${ }^{[12]}$. 颗粒物中的 重金属、多环芳烃(polycyclic aromatic hydrocarbon, $\mathrm{PAH})$ 、总碳、纳米颗粒等可通过不同途径影响细胞, 包括损伤线粒体、生成活性氧、增加细胞因子等炎症 介质 ${ }^{[29 \sim 34]}$.

人类作为需氧生物体, 每日在摄人氧的同时也 不断生成很多活性氧类副产品, 在体内抗氧化系统 的作用下, 机体维持着相对稳定的氧化还原平衡态. 氧化还原平衡失调后, 可对体内基因转录、信号转 导、生物大分子活性等产生影响，包括炎症反应通路 中涉及到的蛋白、基因等，从而导致炎症反应. 烟酰 胺腺嘌呤二核苷酸磷酸氧化酶(NADPH oxidase)、线 粒体等是胞内主要的活性氧来源. 加州大学Nel课题 组 ${ }^{[40 ~ 44]}$ 在颗粒物氧化损伤方面进行了很多相关研究, 以柴油车排放颗粒物(diesel exhaust particles, DEP)、 超细颗粒物等作为研究对象, 发现其中的有机化学 组分是激发活性氧产生的主要成分, 可引起血红素 加氧酶(heme oxygenase-1, HO-1)、谷胱甘肽 $S$ 转移酶 (glutathione-S-transferase, GST)等氧化损伤相关基因 的表达变化, 表现为线粒体膜电势下降、脱氧核糖核 酸(DNA)损伤、炎症细胞因子升高、细胞程序性死亡 等，而抗氧化剂则可一定程度上降低上述指标，表明 


\section{表 1 大气污染物化学组分的促炎症效应研究报道}

Table 1 Pro-inflammatory effects of ambient chemical pollutants

\begin{tabular}{|c|c|c|c|}
\hline 组分 & 实验类型 & 炎症介质 & 参考文献 \\
\hline 臭氧 $(0.1 \sim 1 \mathrm{ppm}, 1 \mathrm{~h})^{\mathrm{a})}$ & 肺泡巨噬细胞、气道上皮细胞 & IL-6, IL-8, 纤维蛋白原 & [34] \\
\hline 臭氧 $(0 \sim 500 \mathrm{ppb}, 6 \mathrm{~h})^{\mathrm{a})}$ & 气道上皮细胞 & IL-8, GM-CSF, TNF, sICAM-1 ${ }^{\text {b) }}$ & [35] \\
\hline 油飞灰颗粒物 & 气道上皮细胞 & IL-6, IL-8, TNF & [36] \\
\hline $\mathrm{PM}_{2.5}$ 有机提取物 & 人支气管上皮细胞 & IL-6, IL-1 $\beta$ & [33] \\
\hline 吸烟颗粒物, 臭氧 & 动物实验 & IL-6 & {$[37]$} \\
\hline $\mathrm{PM}_{10}$ & 动物实验 & IL-1 $\beta, \mathrm{COX}^{-2^{\mathrm{c}}}$ & {$[31]$} \\
\hline $\mathrm{PM}_{2.5}$ & 人群实验 & $\mathrm{CRP}$, 纤维蛋白原 & [4] \\
\hline $\mathrm{PM}_{2.5}, \mathrm{SO}_{2}, \mathrm{NO}_{2}$ & 哮喘儿童 & 脂质过氧化产物TBARS & {$[11]$} \\
\hline $\mathrm{PM}_{2.5}\left(\mathrm{OC}, \mathrm{NO}_{3}^{-}, \mathrm{SO}_{4}^{2-}\right)$ & 人群实验 & $\mathrm{CRP}$, 纤维蛋白原, 白细胞 & {$[38]$} \\
\hline $\mathrm{PM}_{10}$ & 人群实验 & 8-iso-PGF2a, 8-OHdG ${ }^{\mathrm{d}}$ & [39] \\
\hline
\end{tabular}

a) $1 \mathrm{ppm} \mathrm{O} \mathrm{O}_{3}=1000 \mathrm{ppb} \mathrm{O}=2143 \mu \mathrm{g} / \mathrm{m}^{3} \mathrm{O}_{3}$; b) GM-CSF, 粒细胞-巨噬细胞集落刺激因子; TNF, 肿瘤坏死因子; sICAM-1, 可溶性细 胞粘附因子-1; c) COX-2, 环氧化酶 2; d) 8-iso-PGF2a, 人8异前列腺素F2a; 8-OHdG, 8-差基脱氧鸟苷

了氧化损伤在颗粒物促炎症效应的作用. 石棉、二氧 化硅等颗粒物可激活 NADPH氧化酶释放活性氧, 继 而激活核苷酸结合寡聚化结构域样受体(NALP3)炎 症小体(NACHT(神经元调亡抑制蛋白(NAIP)、MHC 类别 2 转录激活因子 (C2TA) 、异核体不相容性 (HET-E)和端粒酶相关蛋白1(TP1), 富含亮氨酸重复 序列(LRR)和萠蛋白之后的PYRIN结构域(PYD)), 导 致炎症介质 IL- $1 \beta$ 等的释放 ${ }^{[45]}$. 除了关于颗粒物化学 组分和炎症细胞因子相关性的研究报道, 血液或尿 液中的DNA损伤标志物 8-OHdG, 丙二醛(MDA)等氧 化损伤生物标志物和铁离子、黑炭等组分之间的显著 关联也被证实 ${ }^{[39]}$. 此外, 活性氮类物质也可引起胞 内氧化损伤. 研究发现DEP和纳米颗粒物等通过刺 激胞内一氧化氮释放引起蛋白硝基化, 导致了胞内 炎症反应, 与呼吸系统疾病及帕金森症、阿尔茨海默 病等神经退化性疾病有明确关联 ${ }^{[46,47]}$. 在刺激胞内 活性氧或者活性氮类物质生成的同时, 胞内抗氧化 防御体系, 包括抗氧化酶 (extracellular superoxide dismutase, EC-SOD)、小分子抗氧化剂 (glutathione, $\mathrm{GSH}$ )等也受到颗粒物中的重金属、硝酸根离子 $\mathrm{NO}_{3}^{-}$, 氯离子 $\mathrm{Cl}^{-}$的明显影响 ${ }^{[43,48,49]}$. 当前, 颗粒物氧化潜 势主要通过基于细胞和非细胞的方法进行评价, 非 细胞评价方法包括二硫苏糖醇 (dithiothreitol, DTT)、 苂光探针 $2^{\prime}, 7^{\prime}$-二氯苂光黄双乙酸盐 (DCFA-DA) 等, 尽管不同方法得到的颗粒物氧化潜势有所差别, 但 炎症反应和颗粒物的氧化潜势在单污染物和多污染 物模型下均显著相关 ${ }^{[50]}$. 颗粒物水溶性的醌类有机
物等和重金属是其DTT氧化潜势的主要贡献因子, 同时还可和模拟肺部流体生成过氧化氢 ${ }^{[51,52]}$. 但也 有部分研究认为颗粒物氧化潜势无法很好地预测颗 粒物的急性炎症效应 ${ }^{[33]}$.

炎症反应中各种炎症介质的释放依赖于效应细 胞的激活, 而该激活过程除了依赖于受体-配体分子 的结合, 同时依赖于胞内的基因转录激活和产物表 达, 受多重因素影响. 蛋白磷酸化和脱磷酸化是对细 胞内信号转导至关重要的生化过程, 污染物可对激 酶(促成蛋白磷酸化)、磷酸酶(促成蛋白脱磷酸化)等 产生影响, 导致相应的下游信号通路变化, 从而产生 炎症反应. 不同种类的重金属对于激酶有不同的影 响, $\mathrm{V}, \mathrm{Zn}$ 等可抑制酪氨酸磷酸酶导致磷酸化酪氨酸 累积, 进而激活丝裂原活化蛋白激酶(mitogen-activated protein kinase, MAPK), 引起炎症效应，而As离子则 没有类似效应 ${ }^{[54]}$. Wu等人 ${ }^{[55,56]}$ 发现 $\mathrm{As}, \mathrm{Cu}, \mathrm{V}, \mathrm{Zn}$ 这 些重金属可促进皮肤增长因子(epidermal growth factor, EGF) 磷酸化, 进而激活丝裂原活化蛋白 (MAP)激酶, 导致细胞炎症反应, 氧化锌纳米颗粒可 以通过 $\mathrm{p} 65$ 和 $\mathrm{I} \kappa \mathrm{B} \alpha$ 的磷酸化和去磷酸化过程影响炎症 介质IL-8的表达和释放, 引起急性肺部炎症. 信号转 导过程的蛋白磷酸化和脱磷酸化受到影响后, 下游 的基因转录和表达也会相应发生变化. 转录因子是 通过和特定DNA序列结合控制基因转录过程实现基 因表达调控目的的蛋白质. 颗粒物有机组分刺激细 胞活性氧产生激活MAP激酶和激活蛋白 $1(\mathrm{AP}-1)$ 、核 因子 $-\kappa B(N F-\kappa B)$ 、核因子-相关因子 $2(N r f 2)$ 等炎症相 
关的转录因子, 使得相关的炎症介质大量表 达 $^{[41,57,58]}$.

\section{2 颗粒物生物组分的炎症效应}

一方面, 颗粒物化学组分的氧化还原活性直接 影响机体氧化还原稳态、免疫系统炎症响应; 另一方 面, 细菌、真菌等微生物组分由于其特有的配体特征, 其促炎症效应也值得重视. 内毒素、葡聚糖等胞壁结 构组分是源于微生物的保守组分, 是结合免疫细胞 表面受体的重要配体分子. 不同地区的空气中内毒 素浓度水平有较大差异, 每毫克 $\mathrm{PM}_{2.5}$ 中的内毒素浓 度从0.3 5.52 EU不等, 与臭氧、二氧化氮、总酸度、 $\mathrm{PM}_{2.5}$ 质量浓度等无明显关联, 和大气温度显著正相

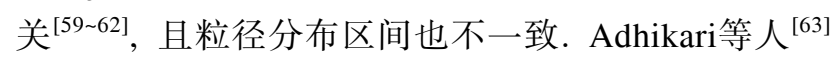
发现1 $\mu \mathrm{m}$ 以下的细颗粒物中含有高浓度的内毒素和 葡聚糖, 前者平均水平为 $22.7 \%$, 可高达 $63 \%$; 后者平 均水平为 $22.6 \%$, 可高达 $96 \%$.

部分研究认为颗粒物的来源及其组分对其毒性 的影响要大于其质量浓度和粒径的影响, 在研究化 学组分促炎症效应的同时, 也有研究探讨了生物组 分内毒素的贡献, 如表2所示, 其中重金属和内毒素 组分的促炎症效应较为突出 ${ }^{[64-66]}$. 通过使用金属鳌 合剂分析重金属在炎症效应中的作用, 发现重金属、 颗粒物DTT氧化潜势等对颗粒物炎症潜势的作用机 制不同于内毒素 ${ }^{[67,68]}$. 人群实验结果表明颗粒物内 毒素、葡聚糖水平和机体炎症反应相关性最强, 即使 是短到2 $\mathrm{h}$ 的颗粒物暴露导致的白细胞上升症状也主 要是由内毒素引起的 ${ }^{[69,70]}$. Schins等人 ${ }^{[71]}$ 的动物实验 认为颗粒物中的 $\mathrm{Fe}, \mathrm{Cu}, \mathrm{V}, \mathrm{Ni}, \mathrm{Cr}, \mathrm{Al}$ 及颗粒物的羟 基自由基生成能力等与其促炎症效应无显著关系, 而内毒素浓度和其促炎症效应显著相关. 通过使用
多黏菌素 $\mathrm{B}$ (polymyxin B)或者脂多糖结合蛋白(LPSbinding protein, LBP)封闭内毒素结合位点开展的实 验室研究发现, 封闭后颗粒物的炎症效应均有显著 下降, 进一步证明了内毒素组分对颗粒物促炎症效 应的重要性 ${ }^{[1,72279]}$. 除了内毒素这些特定的具有直 接促炎症效应的生物组分, 空气中的细菌、真菌也对 老年人群和健康年轻人均有影响, 其变化和人群血 液中的 CRP, IL-6, 白细胞计数等变化有显著相关 性 ${ }^{[80]}$. 有研究中发现年轻健康人体在暴露于污染大 气5 h 后白细胞数量明显上升, 但是该变化与污染物 特征无明显关联, 推测部分原因是由于该研究中污 染物特征仅包括 $\mathrm{PM}_{2.5}, \mathrm{PM}_{10}$, 颗粒物数浓度 $(\mathrm{PNC})$, 有机碳/无机碳( $\mathrm{OC} / \mathrm{EC})$, 铜 $\mathrm{Cu}$, 镍 $\mathrm{Ni}$, 钒 $\mathrm{V}, \mathrm{DTT}$ 氧 化潜势、 $\mathrm{NO}_{2}$ 等化学特征, 而没有包括颗粒物的生物 组分特征. 尽管内毒素成分的季节变化可造成颗粒 物促炎症效应的季节性变化趋势, 但内毒素也不能 完全解释颗粒物的促炎症效应 ${ }^{[81]}$. 总体上目前关于 生物组分的促炎症效应多集中于内毒素这一组分, 未来需要对葡聚糖、壳糖等其他具有配体性质的生物 组分开展充分研究.

除了颗粒物中的生物组分, 颗粒物还可能通过 影响呼吸道微生物环境产生影响. 研究中利用煤燃 烧飞灰、火山灰进行动物和细胞实验发现, 颗粒物可 破坏抗微生物多肽功能损伤呼吸道的微生物清除能 力, 同时颗粒物中的铁可有效促进呼吸道细菌增 长 $^{[88,89]}$.

\section{3 颗粒物生物化学组分的协同炎症效应}

\subsection{1 化学组分在过敏性疾病中的佐剂效应} 过敏反应是花粉、动物皮屑、尘螨等外源性蛋白 过敏原颗粒诱导的病理反应之一. 一项研究中利用

\section{表 2 大气污染物生物组分的促炎症效应研究报道}

Table 2 Pro-inflammatory effects of ambient biological pollutants

\begin{tabular}{|c|c|c|c|}
\hline 组分 & 实验类型 & 炎症介质 & 文献 \\
\hline 内毒素 & 人群实验 & IL-6, IL-8, $\mathrm{FEV}_{1}^{\text {a) }}$ & {$[82]$} \\
\hline 内毒素, 超细颗粒 & 动物实验 & IL-6, 纤维蛋白原 & {$[83]$} \\
\hline $\mathrm{PM}_{10}, \mathrm{PM}_{2.5}$ (内毒素、重金属) & 细胞实验 & TNF, IL-6 & [84] \\
\hline $\mathrm{PM}_{10}, \mathrm{PM}_{2.5}$ (内毒素、重金属) & 细胞实验 & $\mathrm{TNF}$, 花生四烯酸 & {$[85]$} \\
\hline $\mathrm{PM}_{2.5}$ (内毒素、重金属、PAH) & 细胞实验 & IL-1 $\beta$, IL-10 & [86] \\
\hline $\mathrm{PM}_{10}$ (内毒素、重金属、PAH) & 细胞实验 & TNF, IL-8 & [87] \\
\hline $\mathrm{PM}_{10}, \mathrm{PM}_{2.5}$ (内毒素、重金属、PAH等) & 细胞实验 & IL-6 & {$[66]$} \\
\hline
\end{tabular}

a) $\mathrm{FEV}_{1}$ : 最大深吸气后做最大呼气, 最大呼气第 $1 \mathrm{~min}$ 呼出的气量的容积 
调查问卷分别在1964和1989年对苏格兰的过敏性疾 病发病率进行调查, 结果表明, 哮喘发病率从 $4.1 \%$ 上升至 $10.2 \%$, 花粉过敏性疾病从 $3.2 \%$ 升至 $11.9 \%$, 过敏性皮炎从 $5.3 \%$ 升至 $12 \%$, 引起了对大气污染物 与过敏性疾病之间关系的关注, 过敏原在臭氧、二氧 化硫、二氧化氮、DEP等作用下表现出了更强的致敏 性, 尤其是气传过敏原, 如花粉、真菌毒素、动植物 蛋白等 ${ }^{[00]}$. 随着工业源、机动车排放等导致的室外大 气污染越来越严重, 东南亚地区尤其是中国, 哮喘等 过敏性疾病发病率逐渐攀升, 展现出和西方过去相 似的趋势 ${ }^{[91]}$. 除了特定的过敏原, 还需要共刺激信 号, 即炎症信号, 两者相结合起到“双保险”的作用, 才可引起过敏反应 ${ }^{[92]}$. 在疫苗学中, 氢氧化铝等组 分多作为佐剂加人到疫苗中, 通过加强炎症信号增 强疫苗的免疫保护作用 ${ }^{[93]}$. 从 1986年Muranaka等 ${ }^{[94]}$ 的第 1 篇文章开始, 大量动物实验揭示了 DEP的 类似于氢氧化铝的佐剂效应, 主要表现为 DEP可和 过敏源协同导致小鼠产生更多的免疫球蛋白 $\mathrm{E}$ (Immunoglobulin $\mathrm{E}, \mathrm{IgE}$ ), 且再次暴露相同过敏原 时, 前者的 $\operatorname{IgE}$ 持久性更强 ${ }^{[94 ~ 97]}$. 此外, VOC, 颗粒物 有机组分和无机组分、内毒素、葡聚糖等通过激活 Toll样受体2(TLR2)、Toll样受体4(TLR4)等模式识别 受体也有一定的佐剂效应 ${ }^{\left[{ }^{[8 ~} ~ 100\right]}$. 氧化损伤机制在上 述污染物组分的佐剂作用中起到了重要作用 ${ }^{[101 ~ 104]}$. 嗜碱性粒细胞是IL-4(白介素-4, 导致过敏反应的关键 细胞因子)的重要来源, 研究发现抗氧化剂 NAC $(\mathrm{N}-$ 乙酰-半胱氨酸)可抑制由 DEP造成的 IL-4 上升. DEP 中的 $\mathrm{PAH}$ 等有机物和氧化性物质通过激活芳香烃受 体(AhR) 和Nrf2转录因子调控的信号通路起到了增强 炎症信号的佐剂效应 ${ }^{[105 ~ 108]}$.

\subsection{2 化学组分与生物组分的协同炎症效应}

尽管至今仍未完全清楚大气污染对过敏性疾病 的影响机制, 花粉等具有致敏性的生物组分和化学 类颗粒物组分、气态污染物的佐剂协同效应对过敏性 疾病的影响得到越来越多的共识 ${ }^{[109]}$. 同理推测, 颗 粒物内其他非致敏性的生物和化学组分之间也可能 存在协同效应, 或可解释颗粒物的炎症效应. Long 等人 ${ }^{[110]}$ 在 2001 年开展了一项探索性研究, 将同时采 集的室内、室外颗粒物以 $100 \mu \mathrm{g} / \mathrm{mL}$ 暴露处理小鼠巨 噬细胞, 发现室内颗粒物中高浓度的内毒素导致其 促炎症效应强于室外颗粒物, 然而在依据内毒素浓 度对颗粒物的促炎症效应标准化后, 发现室内颗粒
物的促炎症效应依然强于室外颗粒物, 推测是由于 室内颗粒物中的其他组分协同内毒素导致了更强的 炎症效应, 但是文中并未进行进一步研究. $\mathrm{PM}_{2.5}$ 和当 量浓度的碳黑颗粒物的促炎症效应可差 10 倍左右, 意味着 $\mathrm{PM}_{2.5}$ 上吸附的相应组分对其促炎症效应有不 可忽略的作用 ${ }^{[111]}$. 利用标准超细颗粒物开展的细胞 实验结果表明颗粒物单独暴露对炎症介质 COX-2表 达无显著影响, 然而在使用细颗粒物预暴露 $1 \mathrm{~h}$ 后加 人内毒素进行共同暴露处理时, 发现细胞调控脂类 炎症介质的基因表达和蛋白分泌均有显著提高，且 高于单纯的内毒素对照组, 进一步证实了颗粒物化 学组分与内毒素之间的协同炎症效应 ${ }^{[112]}$. 另外一项 研究使用模拟环境中生成的颗粒物开展了细胞实验, 发现该颗粒物抑制了上皮细胞释放的IL-8浓度，推测 与模拟生成颗粒物中无内毒素或内毒素浓度极低有 关 ${ }^{[113]}$. 此外, PAH在细胞实验中也表现出与内毒素 的协同炎症效应 ${ }^{[14]}$. 一项 2015年的研究中, 通过抑 制细胞吞噬、抑制TLR4, MAP激酶(细胞外信号调节 激酶p 38 , 细胞外信号调节激酶ERK $1 / 2$ ) 等实验设计, 发现纳米颗粒物和内毒素的协同炎症效应主要是由 纳米颗粒物在胞内环境中促进磷酸化刺激TLR4受体 相关的炎症信号通路而造成的 ${ }^{[115]}$.

越来越多的研究发现单单依靠颗粒物的化学组 分或者内毒素等生物组分仍难以完全解释颗粒物的

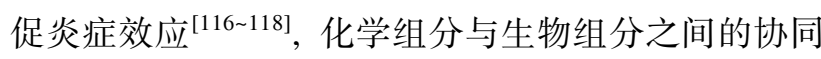
效应或许有助于解释其促炎症效应. 然而, 目前关于 颗粒物生物、化学组分的协同炎症效应的研究仍然较 少, 未来亟待通过学科间交叉结合, 综合研究颗粒物 的各项特征进而解释其促炎症效应.

\section{2 展望}

炎症反应尤其是慢性炎症是引起不同类型疾病 的重要病理学机制之一, 大气颗粒物及气态污染物 的促炎症能力已被流行病学观察实验、人群实验、动 物实验、细胞实验等证实, 然而对于颗粒物这种复杂 的污染物类型，其导致炎症效应的关键因子仍不明 确, 病理学机制也不清楚. 在线监测技术的发展使得 各项化学污染物监测变得简单易行, 而生物组分由 于其特有的生物学特性, 仍然缺乏简单高效的监测 手段，导致对其时空分布特征等认识依然有限，从而 难以评估生物组分对颗粒物促炎症效应的贡献. 鉴 于生物组分在激活免疫系统方面的独有“优势”，对 
其种类、浓度等特征开展大量研究显得尤为必要. 生 物组分和化学组分究竟哪一类是导致炎症因子的主 要贡献者，两者如何协同作用也还没有明确答案.

除了颗粒物本身含有的生物组分, 颗粒物对人体 微生物的影响也是一个需要考虑的问题. 近年来人体 微生物组学发展迅速, 其数量是人体自身细胞数量的 10 倍左右, 微生物和人组成的超级共存体已得到越来 越多的共识, 微生物组在维持机体健康中的重要性不 言而喻 ${ }^{[119,120]}$. 呼吸道并不是无菌的, 含有丰富的微 生物, 对于呼吸系统健康乃至机体健康也至关重 要 ${ }^{[121,122]}$. 颗粒物通过呼吸作用人肺后, 是否会和呼 吸道的微生物组分相互作用影响呼吸道免疫平衡, 吸 人的颗粒物等污染物是否会通过影响呼吸道内的微生
物群落稳态间接影响呼吸道免疫系统平衡, 回答这些 问题对于厘清大气污染物的健康效应机制有重要意义.

根据当前关于大气污染健康效应的研究现状, 建议如下：(1) 研究大气污染对空气中生物组分特征 的影响, 尤其是在重污染天气期间细菌、真菌、病毒 等微生物气溶胶及其组分如内毒素、葡聚糖、核糖核 酸RNA等的变化, 为评估生物组分的促炎症效应的 贡献提供基础数据. (2) 深人研究内毒素等生物组分 和不同类型的化学组分(包括硝酸盐、硫酸盐、有机 碳、无机碳、二次有机气溶胶、重金属、臭氧、氮氧 化物、二氧化硫)共同作用下的促炎症效应和机制. (3) 研究呼吸道微生物群落在大气污染影响下的动态变 化, 为研究颗粒物健康效应提供新的可能解释.

\section{参考文献}

1 Bostrom C E, Gerde P, Hanberg A, et al. Cancer risk assessment, indicators, and guidelines for polycyclic aromatic hydrocarbons in the ambient air. Environ Health Perspect, 2002, 110(Suppl 3): 451-488

2 Pope C A, Burnett R T, Thun M J, et al. Lung cancer, cardiopulmonary mortality, and long-term exposure to fine particulate air pollution. JAMA, 2002, 287: 1132-1141

3 Brunekreef B, Holgate S T. Air pollution and health. Lancet, 2002, 360: 1233-1242

4 Hoffmann B, Moebus S, Dragano N, et al. Chronic residential exposure to particulate matter air pollution and systemic inflammatory markers. Environ Health Perspect, 2009, 117: 1302-1308

5 Anderson J O, Thundiyil J G, Stolbach A. Clearing the air: A review of the effects of particulate matter air pollution on human health. J Med Toxicol, 2012, 8: 166-175

6 Kim J W, Park S, Lim C W, et al. The role of air pollutants in initiating liver disease. Toxicol Res, 2014, 30: 65-70

7 Lee B J, Kim B, Lee K. Air pollution exposure and cardiovascular disease. Toxicol Res, 2014, 30: 71-75

8 Brook R D, Rajagopalan S, Pope C A, et al. Particulate matter air pollution and cardiovascular disease: An update to the scientific statement from the american heart association. Circulation, 2010, 121: 2331-2378

9 Chan S H, Van Hee V C, Bergen S, et al. Long-term air pollution exposure and blood pressure in the sister study. Environ Health Perspect, 2015, 123: 951-958

10 Calderon-Garciduenas L, Villarreal-Calderon R, Valencia-Salazar G, et al. Systemic inflammation, endothelial dysfunction, and activation in clinically healthy children exposed to air pollutants. Inhal Toxicol, 2008, 20: 499-506

11 Ling L, Poon R, Li C, et al. Acute effects of air pollution on pulmonary function, airway inflammation, and oxidative stress in asthmatic children. Environ Health Perspect, 2009, 117: 668-674

12 Liu C, Xu X, Bai Y, et al. Air pollution-mediated susceptibility to inflammation and insulin resistance: Influence of CCR2 pathways in mice. Environ Health Perspect, 2014, 122: 17-26

13 Verones B, Oortgiesen M. Neurogenic inflammation and particulate matter (PM air pollutants). Neurotoxicology, 2001, 22: 795-810

14 Calderóngarcidueñas L, Francolira M, Torresjardón R, et al. Pediatric respiratory and systemic effects of chronic air pollution exposure: Nose, lung, heart, and brain pathology. Toxicol Pathol, 2007, 35: 154

15 Kioumourtzoglou M A, Schwartz J D, Weisskopf M G, et al. Long-term $\mathrm{PM}_{2.5}$ exposure and neurological hospital admissions in the northeastern united states. Environ Health Perspect, 2016, 124: 23-29

16 Genc S, Zadeoglulari Z, Fuss S H, et al. The adverse effects of air pollution on the nervous system. J Toxicol, 2012, 2012: 782462

17 Lelieveld J, Evans J S, Fnais M, et al. The contribution of outdoor air pollution sources to premature mortality on a global scale. Nature, 2015, 525: 367-371

18 Pope C A, Burnett R T, Thurston G D, et al. Cardiovascular mortality and long-term exposure to particulate air pollution: Epidemiological evidence of general pathophysiological pathways of disease. Circulation, 2004, 109: 71-77 
19 Block M L, Calderon-Garciduenas L. Air pollution: Mechanisms of neuroinflammation and CNS disease. Trends Neurosci, 2009, 32: 506-516

20 Voter K Z, Whitin J C, Torres A, et al. Ozone exposure and the production of reactive oxygen species by bronchoalveolar cells in humans. Inhal Toxicol, 2001, 13: 465-483

21 Chuang K J, Chan C C, Su T C, et al. The effect of urban air pollution on inflammation, oxidative stress, coagulation, and autonomic dysfunction in young adults. Am J Respir Crit Care Med, 2007, 176: 370-376

22 Martinez-Lazcano J C, Gonzalez-Guevara E, del Carmen Rubio M, et al. The effects of ozone exposure and associated injury mechanisms on the central nervous system. Rev Neurosci, 2013, 24: 337-352

23 Kahle J J, Neas L M, Devlin R B, et al. Interaction effects of temperature and ozone on lung function and markers of systemic inflammation, coagulation, and fibrinolysis: A crossover study of healthy young volunteers. Environ Health Perspect, 2015, 123: 310-316

24 Mirowsky J E, Jin L, Thurston G, et al. In vitro and in vivo toxicity of urban and rural particulate matter from california. Atmos Environ, 2015, 103: 256-262

25 Wang B, Li K X, Jin W J, et al. Properties and inflammatory effects of various size fractions of ambient particulate matter from Beijing on a549 and j774a.1 cells. Environ Sci Technol, 2013, 47: 10583-10590

26 Akhtar U S, Rastogi N, McWhinney R D, et al. The combined effects of physicochemical properties of size-fractionated ambient particulate matter on in vitro toxicity in human a549 lung epithelial cells. Toxicol Rep, 2014, 1: 145-156

27 Hetland R B, Cassee F R, Refsnes M, et al. Release of inflammatory cytokines, cell toxicity and apoptosis in epithelial lung cells after exposure to ambient air particles of different size fractions. Toxicol In Vitro, 2004, 18: 203-212

28 Akira S, Uematsu S, Takeuchi O. Pathogen recognition and innate immunity. Cell, 2006, 124: 783-801

29 Jaimes E A, Sweeney C, Raij L. Effects of the reactive oxygen species hydrogen peroxide and hypochlorite on endothelial nitric oxide production. Hypertension, 2001, 38: 877-883

30 Wei K, Zheng Y H, Li J, et al. Microbial aerosol characteristics in highly polluted and near-pristine environments featuring different climatic conditions. Sci Bull, 2015, 60: 1439-1447

31 Guo L, Li B, Miao J J, et al. Seasonal variation in air particulate matter $\mathrm{PM}_{10}$ exposure-induced ischemia-like injuries in the rat brain. Chem Res Toxicol, 2015, 28: 431-439

32 Cao Y, Roursgaard M, Danielsen P H, et al. Carbon black nanoparticles promote endothelial activation and lipid accumulation in macrophages independently of intracellular ros production. PLoS One, 2014, 9: e106711

33 Fuentes-Mattei E, Rivera E, Gioda A, et al. Use of human bronchial epithelial cells (BEAS-2B) to study immunological markers resulting from exposure to $\mathrm{PM}_{2.5}$ organic extract from Puerto Rico. Toxicol Appl Pharmacol, 2010, 243: 381-389

34 Devlin R B, McKinnon K P, Noah T, et al. Ozone-induced release of cytokines and fibronectin by alveolar macrophages and airway epithelial cells. Am J Physiol, 1994, 266: 612-619

35 Rusznak C, Devalia J L, Sapsford R J, et al. Ozone-induced mediator release from human bronchial epithelial cells in vitro and the influence of nedocromil sodium. Eur Respir J, 1996, 9: 2298-2305

36 Veronesi B, Oortgiesen M, Carter J D, et al. Particulate matter initiates inflammatory cytokine release by activation of capsaicin and acid receptors in a human bronchial epithelial cell line. Toxicol Appl Pharmacol, 1999, 154: 106-115

$37 \mathrm{Yu}$ M. The role of interleukin-6 in pulmonary inflammation and injury induced by exposure to environmental air pollutants. Toxicol Sci, 2002, 68: 488-497

38 Strak M, Hoek G, Godri K J, et al. Composition of pm affects acute vascular inflammatory and coagulative markers-The raptes project. PLoS One, 2013, 8: e58944

39 Bertazzi P A, Cantone L, Pignatelli P, et al. Does enhancement of oxidative stress markers mediate health effects of ambient air particles? Antioxid Redox Sign, 2014, 21: 46

40 Hiura T S, Kaszubowski M P, Li N, et al. Chemicals in diesel exhaust particles generate reactive oxygen radicals and induce apoptosis in macrophages. J Immunol, 1999, 163: 5582-5591

41 Nel A E, Diaz-Sanchez D, Li N. The role of particulate pollutants in pulmonary inflammation and asthma: Evidence for the involvement of organic chemicals and oxidative stress. Curr Opin Pulm Med, 2001, 7: 20-26

42 Li N, Wang M, Oberley T D, et al. Comparison of the pro-oxidative and proinflammatory effects of organic diesel exhaust particle chemicals in bronchial epithelial cells and macrophages. J Immunol, 2002, 169: 4531-4541

43 Li N, Sioutas C, Cho A, et al. Ultrafine particulate pollutants induce oxidative stress and mitochondrial damage. Environ Health Perspect, 2003, 111: 455-460

44 Vinzents P S, Moller P, Sorensen M, et al. Personal exposure to ultrafine particles and oxidative DNA damage. Environ Health Perspect, 2005, 113: 1485-1490 
45 Dostert C, Petrilli V, Van Bruggen R, et al. Innate immune activation through nalp3 inflammasome sensing of asbestos and silica. Science, 2008, 320: 674-677

46 Xiao G G, Nel A E, Loo J A. Nitrotyrosine-modified proteins and oxidative stress induced by diesel exhaust particles. Electrophoresis, 2005, 26: 280-292

47 Davis D A, Akopian G, Walsh J P, et al. Urban air pollutants reduce synaptic function of cal neurons via an nmda/no pathway in vitro. J Neurochem, 2013, 127: 509-519

48 Pardo M, Shafer M M, Rudich A, et al. Single exposure to near roadway particulate matter leads to confined inflammatory and defense responses: Possible role of metals. Environ Sci Technol, 2015, 49: 8777-8785

49 Wu S, Wang B, Yang D, et al. Ambient particulate air pollution and circulating antioxidant enzymes: A repeated-measure study in healthy adults in Beijing, China. Environ Pollut, 2016, 208: 16-24

50 Janssen N A H, Strak M, Yang A, et al. Associations between three specific a-cellular measures of the oxidative potential of particulate matter and markers of acute airway and nasal inflammation in healthy volunteers. Occup Environ Med, 2015, 72: 49-56

51 Verma V, Fang T, Xu L, et al. Organic aerosols associated with the generation of reactive oxygen species (ROS) by water-soluble PM 2.5 Environ Sci Technol, 2015, 49: 4646-4656

52 Charrier J G, McFall A S, Richards-Henderson N K, et al. Hydrogen peroxide formation in a surrogate lung fluid by transition metals and quinones present in particulate matter. Environ Sci Technol, 2014, 48: 7010-7017

53 Strak M, Janssen N A, Godri K J, et al. Respiratory health effects of airborne particulate matter: The role of particle size, composition, and oxidative potential-the raptes project. Environ Health Perspect, 2012, 120: 1183-1189

54 Samet J M, Silbajoris R, Wu W, et al. Tyrosine phosphatases as targets in metal-induced signaling in human airway epithelial cells. Am J Respir Cell Mol Biol, 1999, 21: 357

$55 \mathrm{Wu}$ W, Graves L M, Jaspers I, et al. Activation of the egf receptor signaling pathway in human airway epithelial cells exposed to metals. Am J Physiol, 1999, 277: 924-931

$56 \mathrm{Wu} \mathrm{W}$, Samet J M, Peden D B, et al. Phosphorylation of p65 is required for zinc oxide nanoparticle-induced interleukin 8 expression in human bronchial epithelial cells. Environ Health Perspect, 2010, 118: 982-987

57 Donaldson K, Stone V, Borm P J, et al. Oxidative stress and calcium signaling in the adverse effects of environmental particles (PM ${ }_{10}$ ). Free Radic Biol Med, 2003, 34: 1369-1382

58 Li N, Nel A E. Role of the NRF2-mediated signaling pathway as a negative regulator of inflammation: Implications for the impact of particulate pollutants on asthma. Antioxid Redox Sign, 2006, 8: 88-98

59 Mueller-Anneling L, Avol E, Peters J M, et al. Ambient endotoxin concentrations in PM 10 from southern california. Environ Health Perspect, 2004, 112: 583

60 Dong S, Yao M. Exposure assessment in Beijing, China: Biological agents, ultrafine particles, and lead. Environ Monit Assess, 2010, 170 331-343

61 Degobbi C, Saldiva P H N, Rogers C. Endotoxin as modifier of particulate matter toxicity: A review of the literature. Aerobiologia, 2011, 27: $97-105$

62 Guan T, Yao M, Wang J, et al. Airborne endotoxin in fine particulate matter in Beijing. Atmos Environ, 2014, 97: 35-42

63 Adhikari A, Reponen T, Rylander R. Airborne fungal cell fragments in homes in relation to total fungal biomass. Indoor Air, 2013, 23: $142-147$

64 Øvrevik J, Låg M, Holme J A, et al. Cytokine and chemokine expression patterns in lung epithelial cells exposed to components characteristic of particulate air pollution. Toxicology, 2009, 259: 46-53

65 Thomson E M, Breznan D, Karthikeyan S, et al. Cytotoxic and inflammatory potential of size-fractionated particulate matter collected repeatedly within a small urban area. Part Fibre Toxicol, 2015, 12: 24

66 Thomson E M, Breznan D, Karthikeyan S, et al. Contrasting biological potency of particulate matter collected at sites impacted by distinct industrial sources. Part Fibre Toxicol, 2016, 13: 65

67 Maaike S, Ilse G, Maciej S, et al. In vitro toxicity of particulate matter (PM) collected at different sites in the netherlands is associated with PM composition, size fraction and oxidative potential—The raptes project. Part Fibre Toxicol, 2011, 8: 26

68 Monn C, Becker S. Cytotoxicity and induction of proinflammatory cytokines from human monocytes exposed to fine (PM ${ }_{2.5}$ ) and coarse particles $\left(\mathrm{PM}_{10-2.5}\right)$ in outdoor and indoor air. Toxicol Appl Pharmacol, 1999, 155: 245-252

69 Behbod B, Urch B, Speck M, et al. Endotoxin in concentrated coarse and fine ambient particles induces acute systemic inflammation in controlled human exposures. Occup Environ Med, 2013, 70: 761-767

70 Liu C, Cai J, Qiao L, et al. The acute effects of fine particulate matter constituents on blood inflammation and coagulation. Environ Sci Technol, 2017, 51: 8128-8137 
71 Schins R P, Lightbody J H, Borm P J, et al. Inflammatory effects of coarse and fine particulate matter in relation to chemical and biological constituents. Toxicol Appl Pharmacol, 2004, 195: 1-11

72 Gualtieri M, Ovrevik J, Holme J A, et al. Differences in cytotoxicity versus pro-inflammatory potency of different PM fractions in human epithelial lung cells. Toxicol In Vitro, 2010, 24: 29-39

73 Gangamma S, Patil R S, Mukherji S. Characterization and proinflammatory response of airborne biological particles from wastewater treatment plants. Environ Sci Technol, 2011, 45: 3282-3287

74 Becker S, Soukup J M, Gilmour M I, et al. Stimulation of human and rat alveolar macrophages by urban air particulates: Effects on oxidant radical generation and cytokine production. Toxicol Appl Pharmacol, 1996, 141: 637-648

75 Vogel C F, Garcia J, Wu D, et al. Activation of inflammatory responses in human u937 macrophages by particulate matter collected from dairy farms: An in vitro expression analysis of pro-inflammatory markers. Environ Health, 2012, 11: 17

76 Van Den Heuvel R, Den Hond E, Govarts E, et al. Identification of $\mathrm{PM}_{10}$ characteristics involved in cellular responses in human bronchial epithelial cells (beas-2b). Environ Res, 2016, 149: 48-56

77 Yamada P, Hatta T, Du M, et al. Inflammatory and degranulation effect of yellow sand on rbl-2h3 cells in relation to chemical and biological constituents. Ecotoxicol Environ Saf, 2012, 84: 9-17

78 Gangamma S. Characteristics of airborne bacteria in mumbai urban environment. Sci Total Environ, 2014, 488-489: 70-74

79 Soukup J M, Becker S. Human alveolar macrophage responses to air pollution particulates are associated with insoluble components of coarse material, including particulate endotoxin. Toxicol Appl Pharmacol, 2001, 171: 20-26

80 Faridi S, Naddafi K, Kashani H, et al. Bioaerosol exposure and circulating biomarkers in a panel of elderly subjects and healthy young adults. Sci Total Environ, 2017, 593-594: 380-389

81 Camatini M, Corvaja V, Pezzolato E, et al. $\mathrm{PM}_{10}$-biogenic fraction drives the seasonal variation of proinflammatory response in a549 cells. Environ Toxicol, 2012, 27: 63-73

82 Kline J N, Cowden J D, Hunninghake G W, et al. Variable airway responsiveness to inhaled lipopolysaccharide. Am J Respir Crit Care Med, 1999, 160: 297-303

83 Elder A C P, Gelein R, Azadniv M, et al. Systemic interactions between inhaled ultrafine particles and endotoxin. Ann Occup Hyg, 2002, 46: $231-234$

84 Osorniovargas A R, Bonner J C, Alfaromoreno E, et al. Proinflammatory and cytotoxic effects of mexico city air pollution particulate matter in vitro are dependent on particle size and composition. Environ Health Perspect, 2003, 111: 1289

85 Guastadisegni C, Kelly F J, Cassee F R, et al. Determinants of the proinflammatory action of ambient particulate matter in immortalized murine macrophages. Environ Health Perspect, 2010, 118: 1728-1734

86 Yang L, Liu G, Lin Z, et al. Pro-inflammatory response and oxidative stress induced by specific components in ambient particulate matter in human bronchial epithelial cells. Environ Toxicol, 2016, 31: 923-936

$87 \mathrm{Lu} \mathrm{Y,} \mathrm{Su} \mathrm{S,} \mathrm{Jin} \mathrm{W,} \mathrm{et} \mathrm{al.} \mathrm{Characteristics} \mathrm{and} \mathrm{cellular} \mathrm{effects} \mathrm{of} \mathrm{ambient} \mathrm{particulate} \mathrm{matter} \mathrm{from} \mathrm{Beijing.} \mathrm{Environ} \mathrm{Pollut,} \mathrm{2014,} \mathrm{191:} \mathrm{63-69}$

88 Borcherding $\mathrm{J} \mathrm{A}$, Chen H, Caraballo J C, et al. Coal fly ash impairs airway antimicrobial peptides and increases bacterial growth. PLoS One, 2013, 8: e57673

89 Monick M M, Baltrusaitis J, Powers L S, et al. Effects of Eyjafjallajokull volcanic ash on innate immune system responses and bacterial growth in vitro. Environ Health Perspect, 2013, 121: 691-698

90 Rusznak C, Devalia J L, Davies R J. The impact of pollution on allergic disease. Allergy, 1994, 49: 21-27

91 Zhang Q, Qiu Z, Chung K F, et al. Link between environmental air pollution and allergic asthma: East meets west. J Thorac Dis, 2015, 7: 14

92 Galli S J, Tsai M, Piliponsky A M. The development of allergic inflammation. Nature, 2008, 454: 445-454

93 Alam S, Lukawska J, Corrigan C. Adjuvants in allergy: State of the art. Curr Treat Options Allergy, 2014, 1: 39-47

94 Muranaka M, Suzuki S, Koizumi K, et al. Adjuvant activity of diesel-exhaust particulates for the production of IgE antibody in mice. J Allergy Clin Immunol, 1986, 77: 616-623

95 Takafuji S, Suzuki S, Koizumi K, et al. Diesel-exhaust particulates inoculated by the intranasal route have an adjuvant activity for IgE production in mice. J Allergy Clin Immun, 1987, 79: 639-645

96 Steerenberg P A, Dormans J A, van Doorn C C, et al. A pollen model in the rat for testing adjuvant activity of air pollution components. Inhal Toxicol, 1999, 11: 1109-1122

97 Whitekus M J, Li N, Zhang M, et al. Thiol antioxidants inhibit the adjuvant effects of aerosolized diesel exhaust particles in a murine model for ovalbumin sensitization. J Immunol, 2002, 168: 2560-2567

98 Bonisch U, Bohme A, Kohajda T, et al. Volatile organic compounds enhance allergic airway inflammation in an experimental mouse model. PLoS One, 2012, 7: e39817

99 He M, Ichinose T, Ren Y H, et al. PM $_{2.5}$-rich dust collected from the air in Fukuoka, Kyushu, Japan, can exacerbate murine lung eosinophilia. 
Inhal Toxicol, 2015, 27: 287-299

100 Falcon-Rodrigueza C I, Vizcaya-Ruizc A D, Rosas-Pérez I A, et al. Inhalation of concentrated PM $_{2.5}$ from Mexico City acts as an adjuvant in a guinea pig model of allergic asthma. Environ Pollut, 2017, 228: 474

101 Viera L, Chen K, Nel A, et al. The impact of air pollutants as an adjuvant for allergic sensitization and asthma. Curr Allergy Asthm R, 2009, 9: 327-333

102 Saxon A, Diaz-Sanchez D. Air pollution and allergy: You are what you breathe. Nat Immunol, 2005, 6: 223-226

103 Kang X, Li N, Wang M, et al. Adjuvant effects of ambient particulate matter monitored by proteomics of bronchoalveolar lavage fluid. Proteomics, 2010, 10: 520-531

104 Vinding R K, Stokholm J, Chawes B L K, et al. Blood lipid levels associate with childhood asthma, airway obstruction, bronchial hyperresponsiveness, and aeroallergen sensitization. J Allergy Clin Immunol, 2016, 137: 68-74

105 Suzuki T, Kanoh T, Ishimori M, et al. Adjuvant activity of diesel exhaust particulates (DEP) in production of anti-IgE and anti-IgG1 antibodies to mite allergen in mice. Br Poul Sci, 1993, 34: 187-199

106 Devouassoux G, Saxon A, Metcalfe D D, et al. Chemical constituents of diesel exhaust particles induce il-4 production and histamine release by human basophils. J Allergy Clin Immunol, 2002, 109: 847-853

107 Gilmour M, Jaakkola M S, London S J, et al. How exposure to environmental tobacco smoke, outdoor air pollutants, and increased pollen burdens influences the incidence of asthma. Environ Health Perspect, 2006, 114: 627-633

108 Jaguin M, Fardel O, Lecureur V. Exposure to diesel exhaust particle extracts (DEPe) impairs some polarization markers and functions of human macrophages through activation of AhR and NrF2. PLoS One, 2015, 10: e0116560

109 Cakmak S, Dales R E, Coates F. Does air pollution increase the effect of aeroallergens on hospitalization for asthma? J Allergy Clin Immunol 2012, 129: 228-231

110 Long C M, Suh H H, Kobzik L, et al. A pilot investigation of the relative toxicity of indoor and outdoor fine particles: In vitro effects of endotoxin and other particulate properties. Environ Health Perspect, 2001, 109: 1019-1026

111 Pozzi R, De B B, Paoletti L, et al. Inflammatory mediators induced by coarse $\left(\mathrm{PM}_{2.5-10}\right)$ and fine $\left(\mathrm{PM}_{2.5}\right)$ urban air particles in raw 264.7 cells. Toxicology, 2003, 183: 243-254

112 Hofer T P, Bitterle E, Beck-Speier I, et al. Diesel exhaust particles increase LPS-stimulated COX-2 expression and pge2 production in human monocytes. J Leukoc Biol, 2004, 75: 856-864

113 Kooter I M, Alblas M J, Jedynska A D, et al. Alveolar epithelial cells (a549 exposed at the air-liquid interface to diesel exhaust: First study in TNO's powertrain test center. Toxicol in Vitro, 2013, 27: 2342-2349

114 Tsai J R, Cheng H L, Huang S K, et al. Pahs enhance the endotoxin-induced reactive oxygen species and inflammation of human bronchial epithelial cells. Am J Respirat Crit Care Med, 2017, 195: A6844

115 Bianchi M G, Allegri M, Costa A L, et al. Titanium dioxide nanoparticles enhance macrophage activation by lps through a tlr4-dependent intracellular pathway. Toxicol Res, 2015, 4: 385-398

116 Goulaouic S, Foucaud L, Bennasroune A, et al. Effect of polycyclic aromatic hydrocarbons and carbon black particles on pro-inflammatory cytokine secretion: Impact of pah coating onto particles. J Immunotoxicol, 2008, 5: 337-345

117 Jalava P, Wang Q, Kuuspalo K, et al. Day and night variation in chemical composition and toxicological responses of size segregated urban air PM samples in a high air pollution situation. Atmos Environ, 2015, 120: 427-437

118 Hetland R B, Cassee F R, Lag M, et al. Cytokine release from alveolar macrophages exposed to ambient particulate matter: Heterogeneity in relation to size, city and season. Part Fibre Toxicol, 2005, 2: 4

119 Relman D A. Microbiology learning about who we are. Nature, 2012, 486: 194-195

120 Riiser A. The human microbiome, asthma, and allergy. Allergy Asthma Clin Immunol, 2015, 11: 35

121 Huang Y J, Boushey H A. The microbiome in asthma. J Allergy Clin Immunol, 2015, 135: 25-30

122 Adar S D, Huffnagle G B, Curtis J L. The respiratory microbiome: An underappreciated player in the human response to inhaled pollutants? Ann Epidemiol, 2016, 26: 355-359 
Summary for “大气颗粒物生物化学组分的促炎症效应研究进展”

\title{
Pro-inflammatory effects of airborne particulate matters in relation to biological and chemical composition
}

\author{
Fangxia Shen", Tianle Zhu \& Mutong Niu \\ School of Space and Environment, Beihang University, Beijing 102206, China \\ * Corresponding author, E-mail: fxshen@buaa.edu.cn
}

Exposure to air pollution has been linked to various adverse health effects, including respiratory diseases, cardiovascular diseases as well as neurological diseases by numerous epidemiological and toxicological studies. Pro-inflammatory effect is suggested to be one of the major mechanisms regarding the health risks posed by pollutants, especially particulate matter (PM). Although the impacts of particle sources and compositions on the discrepancy of elicited inflammation have gained growing attentions, the key determinants remain unclear. Chemical components, i.e., sulfates, nitrates, trace metals, polycyclic aromatic hydrocarbons, have been most closely associated with inflammatory effects. Bioaerosols (short for biological aerosols) including bacteria, fungi, virus, pollen as well as their debris, feature the unique "ligand" properties in activating the receptors of the innate immune cell and evoking inflammation. Nonetheless, with the challenge of identification and characterization of bioaerosols in a real-time manner remaining, there were still limited studies discussing the inflammation induced by bioaerosols. We present a short summary of the pro-inflammatory effects of airborne particles including bioaerosols and chemical composition. Studies on the indispensable role of oxidative stress in promoting cellular inflammatory cytokine production were summarized. Specifically, chemical compositions of PM could affect cellular inflammatory responses via affecting various phosphatase, kinase (e.g., mitogen-activated protein kinase, tyrosine phosphatase), as well as the transcription factors (e.g. NF- $\mathrm{kB}, \mathrm{Nrf2}$ ). Moreover, the role of the PM-borne biological components, e.g. lipopolysaccharide (LPS), was also summarized. Whereas, neither chemical components nor biological components could fully elucidate the PM-induced inflammation. Notably, synergistic effects between PM and allergens were largely discussed with respect to the high prevalence and severity of allergic diseases. Particularly, PM could function as "adjuvant" in elevating the allergic potential of allergens. By taking advantage of this adjuvant function concept, we summarized the past studies on the synergistic effects between chemical and microbial components of particles. Several suggestions are offered for future researches on air pollution-associated health effects: (1) characterize bioaerosols under various weather conditions, aiming to figure out the effects of air pollutants on the airborne microbes; (2) investigate the effects of the interplay between microbial components (e.g., LPS, 1,3- $\beta$-glucan) and chemical pollutants (i.e., nitrates, sulfates, organic carbon, elemental carbon, secondary organic aerosols, trace metals, $\mathrm{O}_{3}, \mathrm{NO}_{x}$, and $\mathrm{SO}_{2}$ ) on the development of individual inflammation; (3) study the dynamic change of respiratory microbiota, especially under distinct pollution levels, which might give a new clue to uncover the air pollutants-related adverse health effects.

particulate matter, bioaerosols, chemical composition, inflammatory effects, synergistic effects, oxidative stress doi: 10.1360/N972017-01063 